\title{
Universiteit
}

Leiden

The Netherlands

\section{Cutaneous squamous cell carcinoma is associated with Lynch syndrome: widening the spectrum of Lynch syndrome-associated} \section{tumours}

Ykema, B.L.M.; Adan, F.; Crijns, M.B.; Bleeker, F.E.; Dekker, E.; Bekkenk, M.W.; ... ; vanLeerdam, M.E.

\section{Citation}

Ykema, B. L. M., Adan, F., Crijns, M. B., Bleeker, F. E., Dekker, E., Bekkenk, M. W., ... VanLeerdam, M. E. (2021). Cutaneous squamous cell carcinoma is associated with Lynch syndrome: widening the spectrum of Lynch syndrome-associated tumours, 185(2), 462-463. doi:10.1111/bjd.20139

Version: $\quad$ Publisher's Version

License: $\quad$ Creative Commons CC BY 4.0 license

Downloaded from: https://hdl.handle.net/1887/3270992

Note: To cite this publication please use the final published version (if applicable). 
2 National Cancer Registration and Analysis Service. COVID dashboard - cancer. Available at: https://cancerstats.ndrs.nhs.uk/RCRD/COV IDDashboard (last accessed 30 April 2021).

3 National Cancer Registration and Analysis Service. Rapid Cancer Registration Dataset - rapid data outputs. Available at: http://www. ncin.org.uk/collecting_and_using_data/rcrd?upid=425\# outputs (last accessed 30 April 2021).

4 National Cancer Registration and Analysis Service. Keratinocyte cancer report. Available at: https://cancerstats.ndrs.nhs.uk/COSD/Pa thology/Keratinocyte (last accessed 30 April 2021).

5 Cancer Australia. National and jurisdictional data on the impact of COVID-19 on medical services and procedures in Australia: breast, colorectal, lung, prostate and skin cancers. Available at: https:// www.canceraustralia.gov.au/National_and_jurisdictional_data_on_the_ impact_of_COVID-19_on_medical_services_and_procedures (last accessed 30 April 2021).

6 Asai Y, Nguyen P, Hanna TP. Impact of the COVID-19 pandemic on skin cancer diagnosis: a population-based study. PLOS ONE 2021; 16:e248492.

7 Marson JW, Maner BS, Harding TP et al. The magnitude of COVID19 's effect on the timely management of melanoma and nonmelanoma skin cancers. J Am Acad Dermatol 2021; 84:1100-3.

8 Public Health England. Help us, help you. Accessing NHS services cancer. Available at: https://campaignresources.phe.gov.uk/re sources/campaigns/113-help-us/overview (last accessed 29 April 2021).

Funding sources: none.

Conflicts of interest: S.A., T.O.B., M.K. and G.W.M.M. are officers or employees of the British Association of Dermatologists.

\section{Cutaneous squamous cell carcinoma is associated with Lynch syndrome: widening the spectrum of Lynch syndrome-associated tumours}

\section{DOI: $10.1111 /$ bjd.20139}

DeAR EDITOR, Lynch syndrome (LS) is caused by a germline mutation in one of the mismatch repair (MMR) genes. Individuals with LS have an increased risk of developing colorectal and many other tumours including skin tumours. ${ }^{1}$ Sebaceous neoplasms and keratoacanthomas are skin tumours associated with LS, also known as Muir-Torre syndrome. ${ }^{2}$ For cutaneous squamous cell carcinoma (SCC), an association with LS has been suggested. ${ }^{3-5}$ Recently, a 12 -fold increased risk for sebaceous carcinoma and SCC has been described in individuals with LS compared with the Dutch general population at the age of 60 years. $^{6}$

Our aim was to evaluate whether cutaneous SCC is part of the LS tumour spectrum by evaluating the MMR status of cutaneous SCCs diagnosed in a cohort of individuals with LS. Furthermore, we evaluated the concordance between MMR immunohistochemistry (IHC) and microsatellite instability (MSI) polymerase chain reaction (PCR) testing.
Cutaneous SCCs were identified within a cohort of 331 individuals with LS, with a proven germline mutation, from 194 families, derived from two Dutch hospitals (January 2000 to October 2016), as described previously. ${ }^{6}$ The study was approved by the institutional review board of the Netherlands Cancer Institute (IRBm19-123).

Pathology reports and formalin-fixed paraffin-embedded tissues were obtained for histopathological reassessment. IHC was performed according to standard protocols on slides for MMR proteins for the Ventana immunostainer (Roche Diagnostics Limited, Burgess Hill, UK). The proteins studied were MLH1 (clone ES05; Agilent, Santa Clara, CA, USA), MSH2 (clone G219-1129; Roche), MSH6 (clone EP49; Epitomics, Burlingame, CA, USA) and PMS2 (clone A16-4; Roche). Cutaneous SCCs with absent staining of one or more MMR proteins were considered MMR deficient.

DNA was isolated using a Qiagen extraction kit (Qiagen, Venlo, the Netherlands). A pentaplex PCR-based assay for MSI was performed using fluorescent-labelled primers of five mononucleotide repeat targets (BAT25, BAT26, NR24, NR21 and NR27), followed by fragment analysis. MSI was defined as instability in two or more markers.

In 331 individuals with LS, in total 13 cutaneous SCCs were diagnosed in eight patients (2.4\%) (11 SCCs as described earlier and two additional SCCs identified in 2015 and 2017 within this cohort). Tissue from 10 of these 13 cutaneous SCCs in seven patients was available for further analyses. Three patients were diagnosed with two SCCs each. Two patients were male $(29 \%)$ and the majority were diagnosed with an MSH2 germline mutation (86\%; Table 1). Five patients had a history of dermatological neoplasms prior to SCC diagnosis. The median age at diagnosis of the first cutaneous SCC was 52 years (range 33-60).

MMR IHC and MSI PCR testing were performed in the 10 and nine available cutaneous SCCs, respectively (from one sample there was not enough DNA available). MMR deficiency was detected in all 10 cutaneous SCCs by IHC, with the deficiencies corresponding to the LS germline mutations. MSI PCR demonstrated MSI in three of nine cutaneous SCCs, resulting in a discordance of $67 \%$ between MMR IHC and MSI PCR. All of these three patients had two cutaneous SCCs, with both concordant and discordant results between MMR IHC and MSI PCR (Table 1).

We showed that all cutaneous SCCs diagnosed in individuals with LS were MMR deficient, with loss of staining of MMR proteins corresponding to the known germline mutation, suggesting that SCC is an LS-associated tumour. We assume that MMR-deficient cutaneous SCCs develop by a germline mutation in one of the MMR genes, followed by a second hit of the wildtype copy.

Concordance between MMR IHC and MSI PCR is high for colorectal and endometrial cancer, but a low concordance has been described for other (skin) malignancies. ${ }^{7,8}$ Explanations can be that high tumour turnover is necessary to induce enough detectable MSI or that the standard pentaplex panel is not effective for all tumours. ${ }^{8}$ Therefore, we suggest performing only MMR IHC to detect LS in cutaneous SCC. 
Table 1 Immunohistochemistry (IHC) of mismatch repair (MMR) genes and microsatellite instability (MSI) polymerase chain reaction (PCR) in cutaneous squamous cell carcinoma (SCC) diagnosed in patients with Lynch syndrome

\begin{tabular}{|c|c|c|c|c|c|c|c|c|c|}
\hline $\begin{array}{l}\text { Patient } \\
\text { no. and } \\
\text { sex }\end{array}$ & SCCs & $\begin{array}{l}\text { Lynch } \\
\text { mutation }^{\mathrm{a}}\end{array}$ & $\begin{array}{l}\text { Year } \\
\text { of } \mathrm{dx}\end{array}$ & $\begin{array}{l}\text { Age } \\
\text { at dx } \\
\text { (years) }\end{array}$ & $\begin{array}{l}\text { Location } \\
\text { of SCC }\end{array}$ & MMR IHC & $\begin{array}{l}\text { MSI } \\
\text { PCR }\end{array}$ & $\begin{array}{l}\text { Dermatological } \\
\text { history }\end{array}$ & History of malignancy \\
\hline $1, \mathrm{~F}$ & 1 & MLH1 & 2010 & 52 & Neck & MLH1/PMS2 deficient & MSS & $\begin{array}{l}\text { Sebaceous } \\
\text { adenomas }\end{array}$ & No \\
\hline $2, \mathrm{M}$ & 1 & MSH2 & 2015 & 49 & Unknown & MSH2/MSH6 deficient & MSI & Keratoacanthoma & Yes (CRC) \\
\hline $2, \mathrm{M}$ & 2 & MSH2 & 2017 & 51 & Arm & MSH2/MSH6 deficient & MSS & & \\
\hline $3, \mathrm{~F}$ & 1 & MSH2 & 2004 & 55 & Hand & MSH6 deficient & MSS & No & $\begin{array}{l}\text { Yes (cervical and } \\
\text { endometrial cancer) }\end{array}$ \\
\hline $4, \mathrm{~F}$ & 1 & MSH2 & 2008 & 57 & Chin & MSH2/MSH6 deficient & MSS & Keratoacanthoma & No \\
\hline $4, \mathrm{~F}$ & 2 & MSH2 & 2009 & 58 & Thorax & MSH2/MSH6 deficient & MSI & & \\
\hline $5, F$ & 1 & MSH2 & 2016 & 51 & Hand & MSH2/MSH6 deficient & NA & $\begin{array}{l}\text { Sebaceous adenomas, } \\
\text { basal cell carcinoma, } \\
\text { hidrocystoma }\end{array}$ & No \\
\hline $6, \mathrm{M}$ & 1 & MSH2 & 2015 & 60 & Cheek & MSH2/MSH6 deficient & MSI & $\begin{array}{l}\text { Sebaceous } \\
\text { carcinoma }\end{array}$ & Yes (CRC) \\
\hline 6, M & 2 & MSH2 & 2015 & 60 & Cheek & MSH2/MSH6 deficient & MSS & & \\
\hline $7, \mathrm{~F}$ & 1 & MSH2 & Unknown & 33 & Cheek & MSH2/MSH6 deficient & MSS & No & No \\
\hline
\end{tabular}

We recommend that especially for individuals with a pathogenic mutation in MSH2 or MLH1, information about sun exposure, self-examination and the risk of cutaneous malignancies is important, and a single dermatological consultation may be helpful. Further research is necessary to determine whether it is cost-effective to routinely test MMR status in newly diagnosed cutaneous SCC in the general population, especially when diagnosed at a young age. Moreover, the effect of immunotherapy on MMR-deficient cutaneous SCC is being investigated by ongoing trials, which could also influence the need for MMR testing.

To conclude, cutaneous SCC seems to be part of the LS tumour spectrum. Individuals with LS should be informed about their risk of cutaneous cancers including SCC, and preventive measurements should be provided.

Acknowledgments: We would like to thank the NKI-AVL Core Facility Molecular Pathology \& Biobanking (CFMPB) for supplying NKI-AVL Biobank material and for lab support.

B.L.M. Ykema (D), ${ }^{1}$ F. Adan (D),${ }^{2}$ M.B. Crijns, ${ }^{2}$ F.E. Bleeker (D), ${ }^{3}$ E. Dekker (D), ${ }^{4}$ M.W. Bekkenk, ${ }^{5}$ P. Snaebjornsson (iD ${ }^{6}$ and M.E. vanLeerdam (iD) ${ }^{1,7}$

${ }^{1}$ Department of Gastroenterology and Hepatology; ${ }^{2}$ Department of Dermatology; ${ }^{3}$ Department of Clinical Genetics; ${ }^{4}$ Department of Gastroenterology and Hepatology; ${ }^{5}$ Department of Dermatology, Academic Medical Centre, Amsterdam, the Netherlands; ${ }^{6}$ Department of Pathology, Netherlands Cancer Institute, Amsterdam, the Netherlands; and ${ }^{7}$ Department of Gastroenterology and Hepatology, Leiden University Medical Center, Leiden, the Netherlands

Correspondence: Monique E. van Leerdam.

Email:m.v.leerdam@nki.nl

\section{References}

1 Lynch HT, Snyder CL, Shaw TG et al. Milestones of Lynch syndrome: 1895-2015. Nat Rev Cancer 2015; 15:181-94.

2 Bhaijee F, Brown AS. Muir-Torre syndrome. Arch Pathol Lab Med 2014; 138:1685-9.

3 Adan F, Crijns MB, Dekker E et al. A squamous cell carcinoma in a young woman with Lynch syndrome. Fam Cancer 2019; 18:193-6.

4 Sorscher S. A case of squamous cell carcinoma of the skin due to the molecularly confirmed Lynch syndrome. Hered Cancer Clin Pract 2015; 13:12.

5 Khaddour K, Fields RC, Ansstas M et al. Metachronous cutaneous squamous cell carcinoma in a young patient as the only presenting symptom to uncover Lynch syndrome with MLH1 germline mutation. Hered Cancer Clin Pract 2020; 18:23.

6 Adan F, Crijns MB, Zandstra WSE et al. Cumulative risk of skin tumours in patients with Lynch syndrome. Br J Dermatol 2018; 179:522-3.

7 Gray SE, Kay EW, Leader M et al. Enhanced detection of microsatellite instability and mismatch repair gene expression in cutaneous squamous cell carcinomas. Mol Diagn Ther 2006; 10:327-34.

8 Shia J. The diversity of tumours with microsatellite instability: molecular mechanisms and impact upon microsatellite instability testing and mismatch repair protein immunohistochemistry. Histopathology 2021; 78:485-97.

Funding sources: none.

Conflicts of interest: P.S. has received compensation from MSD, MEDtalks and Bayer for expert opinion. 